1慶友整形外科病院リハビリテーション科, ${ }^{2} \mathrm{ATR}$ 人間情報科学研究所第 3 研究室, 慶應義塾大学医学部リハビリテーション医学教室 大高 洋平 ${ }^{1}$, 大須理英子 ${ }^{2}$, 千野 直一 ${ }^{3}$, 川人 光男 ${ }^{2}$

【はじめに】四肢切断後に，切断肢の感覚が触覚刺激により顔面などの他の身体部位に出現することが報告されてい る. Ramachandran らは上肢切断後に顔面を触られると切断上肢の感覚が出現した症例を報告し，MEGを用いた 検討を行い一次感覚野における再構築を指摘した. 一方で, 幻肢感覚が身体の複数箇所に誘発される例は極めて稀で あり fMRI での検討もない. 今回我々は, 切断肢の表象が多発出現した右上肢切断症例を経験し, fMRIを用いた検 討を行い若干の知見を得たので報告する.【症例】 32 歳男性. 2 年 8 力月前, 機械に上肢を巻き込み上腕近位部にて 切断. 断端形成術後, 2-3 日後より幻肢が出現.さらに, 徐々に切断端部, 右耳, 煩, 頭部および右足底を触られる とあたかも切断肢を触られているような異常感覚を自覚するようになった.【方法】幻肢感覚が誘発される足底部な ど身体各部位（左右）を，ブラシを用いて感覚刺激を与え，fMRI を用いて脳活動を計測した. 解析には SPM 99 を 用いた.【結果および考察】切断肢の幻肢感覚が誘発される右足底や右顔面の触覚刺激において, 左大脳半球の一次 感覚野での明らかな再構築は明らかではなかった. 更なる検討が必要であるが, 本例のような切断後異常感覚の出現 には, 従来より指摘されている一次感覚野での再構築以外のメカニズムが存在する可能性がある.

\title{
I -J1- 2 装飾性に重点をおいた体内力源能動義肢ハンドの開発
}

\section{広島県立保健福祉大学保健福祉学部理学療法学科}

大塚彰, 沖貞明, 金井 秀作, 石倉 隆

【目的】わが国の多くの切断者は, 能動義手による機能を切望しながらも, 実際には装飾義手を選択し装着している という報告が多くなされている. 本研究では, 切断者が望む装飾・能動ハンドの開発に際して, ヒトの把握動作分析 を行い，その結果を設計に反映させ，新しいタイプのハンドを試作した。この際の装飾性を，概観の装飾性，義手操 作時の姿勢などの装飾性, ハンドの動きの装飾性, の 3 点を定義した.【方法】義手操作時の代償動作としての不良 姿勢やハンド部の操作性などにつき, 手関節から末梢に拘束を付してのヒトによる義手模擬操作動作での把握・移動 動作の動作筋電解析および 3 次元動作解析から検討した. とくに, 手先の操作性関してロボット工学で用いられる可 操作性を求めた.【結果および考察】可操作性棈円や体幹および上肢の角度変化などから，ハンドの機能としてハン ドの拇指の外転機能の付加が重要なことが確認された. また，ハンドの駆動方法としてワイヤー・プーリ機構を採用 し, 指の屈曲をケーブルで, 伸展を戻しバネによる随意閉じ方式とした. 以上から，1本のケーブルによる多指・多 関節駆動を可能にしたハンドを試作した。本ハンドは，他動的柔らかさと異径断面物把握機能も可能とした。 また， ヒトの手の運動に近似し・代償動作の軽減を図る装飾性を実現できた.

\section{I -J1- 3 乳幼坚に対する筋電義手装着訓練一2 例報告一}

\author{
兵庫県立総合リハビリテーションセンター整形外科
}

陳＼cjkstart隆明, 澤村 誠志, 司馬 良一, 高田 正三, 津村 暢宏

【はじめに】欧米では乳幼児に対する筋電義手訓練がすでに確立しており，長年にわたり多くの実績を有する，日本 ではそのような体制はなく，先天的に上肢を欠損した児に対するケアーは皆無である. 多くの児はその失われた上肢 の機能を補完されないままであるといっても過言ではない. 我々はすでに成人に対する筋電義手訓練システムを確立 しているので, その経験と知識をもとに乳幼児 2 名に対する筋電義手装着訓練を試み，現在のところ良好な経過をた ぞっているので報告する.【症例】症例 1 ：女児, 先天性前腕欠損. 生後 8 力月で当センター初診. 1 歳 2 力月で装飾 義手を装着開始し, 1 歳 6 カ月で筋電義手を装着し, 訓練を開始した. 2 歳になった現在ハンドの開閉を意識できる ようになっている. 症例 2 : 男児, 先天性前腕欠損. 生後 6 力月で当センター初診. 10 力月で装飾義手を装着開始 し， 1 歳 2 カ月で筋電義手を装着し，訓練を開始した．訓練開始まもなくハンドの開閉を意識できるようになり，1 歳 6 力月の現在両手動作が可能である.【考察】欧米の報告では生後 3-6 カ月で装飾義手を装着し, 生後 10-15 月月 で筋電義手装着を開始するそとし 1 歳 6 カ月頃までにほとんどの児が筋電義手を自主的に使いこなし，筋電義手装 着時期が 1 歳を超えると, 成功率は低くなるという. 症例 2 はほぼ欧米の報告通りの順調な経過であるが, 義手装着 時期の遅れた症例 1 は, 義手操作の上達に時間を要した. 僅か 2 例の経験であるが, 筋電義手装着時期は早いほど, その経過は順調であることが示唆された。 


\title{
I-J1ー 4 FDG PET を用いた大腿切断者の手術前後おける下肢筋代謝の評価
}

\author{
'群馬大学医学部整形外科, 2 群馬大学医学部保健学科理学療法
}

篠崎 哲也 ${ }^{1}$, 山路 雄彦 ${ }^{2}$, 鈴木 慶子 $^{1}$, 渡辺 秀臣 $^{1}$, 高岸 憲二 ${ }^{1}$, 茂原 重雄 ${ }^{2}$

【目的】今回我々は大腿切断術施行症例に扔いて, 手術前後における下肢筋代謝の変化を FDG PET 用いて検討し たので報告する.【症例】症例は 69 歳の女性で, 主訴は右下腿部痛である. 現病歴では, 10 歳に頃右下腿を打撲し, 同年 2 回・翌年 1 回の手術を近医にて受けたが詳細は不明である. 平成元年頃より下腿創部から膿の浸出を認めたが 自然に止まるため放置していた。平成 7 年頃より膿の浸出が止まらなくなった為, 平成 12 年 8 月に当科を紹介受診 した。 下腿の慢性骨髄炎と右膝の著しい可動域制限（伸展 $20^{\circ}$, 屈曲 $-10^{\circ}$ ）を認めた為, 平成 12 年 12 月に大腿遠位 3 分の 2 付近での切断術を施行した。手術施行前後に患者の承諾を得た上で FDG PET と第 38 回の本学会で報告し たプロトコールを用いて腸腰筋, 殿筋, 内転筋の代謝を standardized uptake value（SUV）で評価した.【結果】 切断術施行前の測定では, 健側の大殿筋及び両側の中殿筋の SUV が他の筋と比較して高值を示した. しかし, 切断 術施行後 2 カ月での評価では健側の腸腰筋, 大・中・小殿筋の SUV が患側に比べ高值を示したのに対し, 患側内転 筋の SUV は 3.68 と健側の SUV (0.83) と比べ著しい高值を示した.【考察】筋代謝の面で, 切断前の歩行では高 くない内転筋が大腿義足歩行により著しく高くなることを踏まえると，大腿切断者では手術時の内転筋処理のみなら ず，術前からの内転筋強化を中心としたリハビリプログラムが必要であると考光た.

\section{I -J1- 5 当園で義足を処方した小児下肢切断の 4 例}

愛媛整肢療護園整形外科

杉本 佳久, 藤井 基晴, 日野 雅之, 三宅 良昌

【はじめに】切断全体に占める小児切断の割合は 2 ～4\%と報告されており，小児切断を治療する機会は少ない. 今回 我々は，小児下肢切断 4 例を経験したので報告する.【症例および経過】〔症例 1〕右先天性片側骨盤切断に対して， 生後 10 カ月でカナダ式股義足を処方した. 2 歳 3 カ月の調査時には, 義足と歩行器を併用して歩行していた. 症例 2] 左先天性下腿切断に対して, 生後 1 歳 4 カ月で PTB 式下腿義足を処方した. 左下腿断端の痕跡趾とソケットの 適合性が不良であり，膝下下腿切断を検討したが両親の希望により切断は施行しなかった.〔症例 3〕5 歳時に交通事 故による左下腿不全切断に対して, 他院にて断端形成術が施行されたが, 左膝に $50^{\circ}$ の屈曲拘縮が生じた. 当園での リハビリテーションにより拘縮は改善し, KBM 式の骨格構造義足による歩行が可能となった.〔症例 4〕von Recklinghausen 病による左下腿偽関節に対して, 16 歳時に当園で㯟下下腿切断を施行した. 術後は, Soft dressing 法により断端を管理し，仮義足での歩行訓練を行った。術後 1 カ月で，KBM 式の骨格構造義足により安定した歩行 が可能となり退院した。【考察およびまとめ】当園では, 先天性下肢切断に対して, 運動発達に対する配慮から, 早 期より積極的に義足を作成しているが，切断高位によって義足歩行が安定するまでの期間は異なっていた。また，後 天性の下肢切断の場合, 術後に生じる関節拘縮は義足装着の障害となるため, 術直後より注意が必要である.

\section{I -J1- 6 Purpura fulminans による壊死のため両下腿・両手指切断となった一例}

\author{
川崎医科大学附属川崎病院リハビリテーション科 \\ 臼井 雅宣, 森田 能子
}

\begin{abstract}
【はじめに】我々は Purpura fulminans による壊死のため両下腿切断, 両手指切断となったが両下腿義足作成・家屋 改修にて ADL 改善し自宅復帰が得られた症例を経験したのでここに報告する.【症例】57歳男性, 32 歳時より糖尿 病があり内科にて通院加療中であった. 平成 14 年 3 月 11 日頃より発熱, 下痢等感冒様症状を認め 3 月 19 日内科受 診, 入院を勧められるも帰宅. 同日夜より手足のしびれ, 顔面の紅潮, 四肢体幹に紫斑が急速に拡大してきたため, 救急受診, ICU 入院となった. DIC と診断され内科的加療にて生命は維持できたが 7 病日頃より四肢末端が暗赤色 に変化，15 病日頃には両手指，22 病日頃には両足部が乾性壊死となった。 そのため全身状態の回復を待ち 6 月 25 日 両下腿, 右 $2 \sim 5$ 手指, 左 $1 \sim 5$ 手指切断を行った.リハビリは全身状態の落ち着いた 6 月 18 日より術前訓練を開始, 8 月 20 日には回復期り八病棟移床. 術後の残存四肢の皮膚状態が悪く, 当初は ADL 向上・筋力改善訓練中心で行 い，皮膚状態が義足装着に耐えうる状態となるまで待ち 9 月 13 日両下腿義足作成し歩行訓練を開始した. 義足作成 後も断端皮膚の状態が安定せず長期間となったがその間に家屋改修を行い, ADL 向上, 義足歩行を獲得し在宅復帰 が可能となった.【結論】両下腿, 両手指切断のため自立生活が困難に思われた, しかし本人の ADL獲得や歩行に 対する強い意志があり回復期リハ病棟での協力体制が在宅生活を実現させた. また右母指残存も ADL 獲得には重要 であった.
\end{abstract}




\section{I -J1- 7 腰椎疾患による下肢切断者の歩行障害}

${ }^{1}$ 日本大学医学部整形外科, ${ }^{2}$ 永生病院整形外科

町田 正文 ${ }^{1}$, 今村 安秀 ${ }^{2}$, 松崎 英剛 ${ }^{1}$, 龍 順之助 ${ }^{1}$

【目的】青年前期の下肢切断後に装具を装着し歩行可能であったが, 腰椎疾患のために歩行不能となり, 腰椎疾患に 対する手術により歩行可能となった 2 例を経験したので報告する.【対象および結果】症例 1 は 17 歳時に熱傷後疲痕 拘縮による両側足関節および足部変形にて両側膝下切断後に両側下腿義足にて歩行，階段の昇降が可能であった。 28 歳時に突然歩行不能となり，臨床所見より診断に難渋したが，画像所見より L 4-5 間の椎間板へルニアと確定診断し 手術にて歩行可能となった. 症例 2 は 18 歳時に左下肢挫滅創にて右大腿切断後に大腿義足にて歩行可能であった. 61 歳時肺癌の診断にて右上葉切除が施行されたが，それ以後も歩行は可能であった. 64 歳時より右下肢痛が出現し， 歩行困難となった．馬尾性間欠性跛行などの症状より脊柱管狭窄症を疑い，画像所見よりへルニアを伴う腰部脊柱管 狭窄症と確定診断し，手術にて歩行可能となった。【考察】最近の義肢の著しい進歩により，下肢切断者の日常生活 動作は自立可能となることが多くなり，レクリエーションやスポーツ競技さえも可能となった。しかし，われわれの 症例のように椎間板へルニアや脊柱管狭窄症などの腰椎疾患により突然歩行困難となることもあり, 診断には難渋す る.このような場合, 義足の再チェックアウトは必須であるが, 腰椎疾患も考慮し画像診断を進め, 積極的な治療を 行うことにより歩行能力の回復に努めるべきである.

\section{I -J1- 8 壊死性筋膜炎による股関節離断・広範囲組織切除後に作製した股義足の検討}

北海道大学大学院医学研究科リハビリテーション医学

蓼沼 拓, 浦上 祐司, 土田 隆政, 渡部 一郎, 眞野 行生

【症例】 34 歳男性 $\mathrm{A}$ 群溶連菌感染による壊死性筋膜炎発症, 左股関節離断・左除睪術・左側副部デブリドメン・分 層植皮術を施行された。術後股関節義足を作製し，歩行訓練を行った.【経過】断端部は左側腹部〜左骨盤前面の広 範囲に皮下組織切除・植皮がなされており除圧のためソケットの形状に工夫が必要であった. 坐骨部の皮膚は健常部 が保たれていたため荷重支持については大きな問題はなかったが，義足振り出しの際に植皮部がソケット前壁にあた るため, 皮虐トラブル, 除圧に難渋した. 最終的には義足のみで, 平地歩行・斜面歩行・階段昇降が可能となり退院 となった.【検討】カナダ式股関節義足を作製, ナブコ社製の空圧式膝継手と単軸夕イプの股関節・足関節を使用し た. 膝継手については 4 節リンク膝やインテリ膝も試用したが, 振り出しと接地のコントロールにおいては大腿切断 で見られるほどの歩様の改善は見られなかった. 杖なしでの単独歩行が可能となった時点で歩行解析を行った.【考 察】最終的に歩行時の安定性と本人の自覚的な安定感, 座位をとった際の外観についても考慮した結果, 脚長は健側 より短いものとなった. 動作解析上でも正常な歩行とは異なる一峰性の重心パターンを示した. 断端部の皮下組織を 広範囲に欠く本症例において除圧と脚の振り出しに必要な適合性を両立したソケット製作に試行錯誤が必要であっ た. 股義足の場合, 大腿義足に比べて膝継手の選択の幅が少なかった. 日常生活には十分適応できる歩行能力は獲得 できたが職場復帰に向けての改良が課題として残った。 


\title{
I -J1- 9 乳癌術後の肩関節可動域の短期評価一リンパ節郭清および術式による比較
}

\author{
1静岡県立静岡がんセンターリハビリテーション科, 2 慶應義塾大学医学部リハビリテーション医学教室 \\ 过 哲也 1 , 千野 直一 2
}

【目的】乳癌術後の肩関節可動域が患者の背景因子, リンパ節郭清の程度および術式などの要因により異なるのかど うか検討すること.【方法】 2002 年 9 月から 12 月までの 3 カ月間に，当院でリンパ節郭清を予定した乳癌患者を採 択の条件とした。ティッシュエキスパンダー等による同時再建例は除外した，術前および術後に手術側の肩関節可動 域（ROM）を評価した.すべての患者に対して，当院で作成した乳癌前後のリハビリテーションプログラムを週 5 回行った.【結果】 35 名の患者が採択され，リハビリテーションプログラムの脱落例はなかった. 全例女性で平均年 齢 $54.5 \pm 11.1$ 歳であった. 術後 2 週の肩関節可動域を従属変数, 術式, 年齢, 術前化学療法の有無, リンパ節郭清 のレベル，切除されたリンパ節の個数を独立変数として，ステップワイズ重回帰分析を行ったところ，術式が採択さ れ，乳房温存術が乳房切除術よりも肩関節可動域が良いという結果であった。自由度調整済決定係数は 0.35-0.49 $(\mathrm{P}<0.01)$ であった.【考察】術後の短期間においては, リンパ節郭清の程度よりもむしろ術式が肩関節可動域の制 限に影響が大きく，乳癌術前後リハビリテーションを行う上で考慮すべきであることが示唆された。

\section{I -J1-10がんセンターにおけるリハビリテーション科の役割}

1県立静岡がんセンターリハビリテーション科, 2慶應義塾大学医学部リハビリテーション医学教室

过 哲也 1 , 千野 直一 2

【目的】本院は 2002 年 9 月にベッド数 300 床で一部開院したが，診療科としてリハビリテーション（以下リハ）科を 有するがんセンターは本邦ではじめてである。そこで，開院から 4 カ月間の診療および訓練内容を分析し，がんセン ターにおけるリハの役割を検討した。【方法】 2002 年 9 月〜 12 月までにリ八科に依頼された患者 253 名の診療科，原 発巣, リ八処方の内容等を分析した.【結果】平均年齢は $57.8 \pm 16.3$ 歳 $(2 \sim 90)$, 依頼診療科は乳腺外科, 整形外 科, 緩和医療科, 頭頸科, 食道外科, 血液・幹細胞移植科の順であった. リ八処方は PT 147 件, その内容は開胸・ 開腹手術前後（食道癌, 肺癌など）の呼吸リハ, リコンディショニング目的, 脳・脊髄腫瘍による麻痺への訓練, 松 葉杖歩行訓練，ポジショニングなどであった. OT は 98 件でその内容は乳癌術前後のリハ, 浮腫への対応，上肢麻 痺への訓練などであった。一方，STへの依頼件数は 41 件で，その内容は頭頸部癌術前後のリ八（嬩下・構音訓練 や代替音声訓練), 食道癌術後や放射線治療後の曣下訓練などであった.【考察】本院り八科では治療前からのアプロ 一チ, すなわち各診療科と連携しながら, 手術や化学療法を行う前から患者に接し, 治療後も機能障害を最小限に抑 えるべく，早期から介入して成果を得ている．本院は患者の視点に立った医療，社会復帰を目指すことを大目標にし ており，医療スタッフのリハに対する意識が高いこと，開院準備の段階で各診療科へリハの啓蒙を行ってきたことが 良い効果を生んだと原因と考えられた.

\section{I-J1-11肩甲骨部分切除術を施行した悪性骨軟部腫瘍 2 症例の治療成績}

1済生会和歌山病院リハビリテーション科, ${ }^{2}$ 和歌山県立医科大学整形外科, ${ }^{3}$ 済生会和歌山病院整形外科 南 晋司 ${ }^{1}$, 木下 裕文 $^{3}$, 箜瀬 能三 $^{2}$, 玉置 哲也 ${ }^{2}$

【目的】肩甲骨に発生した悪性骨腫瘍に対し肩甲棘より末梢の肩甲骨体部を切除する肩甲骨部分切除術を施行し比較 的良好な患肢機能を温存できた 2 症例を経験したので報告する.【症例 1】 24 歳, 男性, 多発性外骨腫. 左肩甲骨体 部に発生した二次性軟骨肉腫に対し肩甲棘より末梢の肩甲骨体部を切除する肩甲骨部分切除術を施行した. 術後 7 年 を経過し, 再発, 転移は認めず, 肩関節可動域は外転 150 度, 屈曲 160 度, 外旋 60 度, 内旋 90 度である. 自覚的に は左肩に力が入らない気がしており，持ち上げ動作において 90 度以上外転屈曲すると脱力感を感じている.【症例 2】 83 歳，男性，左肩甲骨体部に発生した原発巣不明の転移性骨腫瘍に対し同様に肩甲骨部分切除術を施行した。術 後 10 カ月での肩関節可動域は外転 80 度, 屈曲 80 度であった.この症例は肺，下顎部に転移巣を認め化学療法を施 行している.【考察】全肩甲骨切除術後の肩関節可動域に関して過去の報告では屈曲, 外転能は 30-40 度と報告され ている. 自験例では肩甲棘上部，関節窩を温存しており全肩甲骨切除に比し肩関節機能は比較的良好であった。 Kurer らは肩甲棘下部より末梢を切除した肩甲骨部分切除術の 4 症例を報告しており，外転 110-180 度，屈曲 110180 度であり，残存する筋の代償肥大を認めたと報告している.今回, 自験例について若干の文献的考察を加え報告 を行う。 